Акушерство та гінекологія

УДК 618.213-06-079.7:612.017.2

\title{
CO.В.Трохимович
}

\section{ОСОБЛИВОСТІ КЛІТИННОГО ТА ГУМОРАЛЬНОГО ІМУНІТЕТУ ЗА УМОВ УСКЛАДНЕНОГО ПЕРЕБІГУ ВАГІТНОСТІ РАННІХ ТЕРМІНІВ}

\author{
ДУ «Інститут педіатрії, акушерства і гінекології НАМН України», м. Київ
}

ОСОБЛИВОСТІ КЛІТИННОГО ТА ГУМОРАЛЬНОГО ІМУНІТЕТУ ЗА УМОВ УСКЛАДНЕНОГО ПЕРЕБІГУ ВАГІТНОСТІ PAHHIX TEPMIHIB. В статті представлені результати дослідження клітинного та гуморального імунітету жінок із загрозою переривання вагітності та з викиднем, що не відбувся, ранніх термінів. Встановлено, що ускладнений перебіг вагітності асоціюється зі збільшенням кількості клітин із кілерною активністю (CD 56 ${ }^{+}$. Виявлені зміни показників специфічних та неспецифічних факторів системного імунітету у жінок із загрозою переривання вагітності та викиднем, що не відбувся, ранніх термінів свідчать про наявність хронічного запального процесу, як однієї'з ланок патогенезу ранніх втрат вагітності.

ОСОБЕННОСТИ КЛЕТОЧНОГО И ГУМОРАЛЬНОГО ИММУНИТЕТА ПРИ ОСЛОЖНЕННОМ ТЕЧЕНИЯ БЕРЕМЕННОСТИ РАННИХ СРОКОВ. В статье представлены результаты исследования клеточного и гуморального иммунитета женщин с угрозой прерывания беременности и с несостоявшимся выкидышем ранних сроков. Установлено, что осложненное течение беременности ассоциируется с увеличением количества клеток с киллерной активностью (CD $\left.56^{+}\right)$. Выявленные изменения показателей специфических и неспецифических факторов системного иммунитета у женщин с угрозой прерывания беременности и с несостоявшимся выкидышем ранних сроков свидетельствуют о наличии хронического воспалительного процесса, как одного из звеньев патогенеза ранних потерь беременности.

THE FEATURES OF CELLULAR AND HUMORAL IMMUNITY IN WOMEN WITH COMPLICATIONS OF PREGNANCY IN EARLY TERMS. The results of the study of cellular and humoral immunity of women with threatened abortion and miscarriage in early terms are presented. Established that complications during pregnancy is associated with an increase in the number of cells with killer activity of $\left(C D 56^{+}\right)$. Identified changes in specific and nonspecific factors of systemic immunity in women with threatened abortion and miscarriage in early terms indicate the presence of chronic inflammation, as one of the pathogenesis link of early pregnancy loss.

Ключові слова: клітинний імунітет, гуморальний імунітет, загроза переривання вагітності, викидень, що не відбувся.

Ключевые слова: клеточный иммунитет, гуморальный иммунитет, угроза прерывания беременности, выкидыш который не'состоялся.

Keywords: the cellular immunity, humoral immunity, missed abortion, threatened miscarriage.

ВСтУП. На ранніх етапах гестації розвиток ембріона забезпечується специфічною перебудовою материнського організму, яка супроводжується морфологічними та функціональними змінами в імунній системі $[1,2]$. Порушення імунологічного балансу, функція якого полягає в розпізнаванні та елімінації чужорідних антигенів, може бути причиною неадекватної відповіді матері на розвиток вагітності, що може призводити до безплідності або втрати вагітності ще на їі ранніх етапах $[3,4]$. В першому триместрі вагітності серед імунних факторів, що призводять до ії ускладненого перебігу та репродуктивних втрат, виділяють наступні: антифосфоліпідний синдром, сумісність подружжя по антигенам системи гістосумісності (HLA), а також порушення клітинно-опосередкованих імунних механізмів, зокрема, в Т-хелперній ланці [5-7].

Мета дослідження: вивчити особливості клітинного та гуморального імунітету у жінок із ускладненим перебігом вагітності ранніх термінів.

МАТЕРІАЛИ ТА МЕТОДИ. Обстежено 70 вагітнихжінок в термінах 4-12 тижнів гестації віком 23-36 років: 32 жінки із загрозливим викиднем (перша група), 23 жінки із викиднем, що не відбувся(друга група), 15 вагітних жінок з одноплідною вагітністю, що нормально розвивається (контрольна група).

Дослідження клітинного імунітету включало в себе кількісну оцінку різних субпопуляцій лімфоцитів (CD $3^{+}$ , $C D 4^{+}, \mathrm{CD} 8+, \mathrm{CD} 16+, \mathrm{CD} 56+, \mathrm{CD} 19+, \mathrm{CD} 25^{+}$,
CD 95+). Визначення фенотипу лімфоїдних клітин проводилось непрямим імунофлюоресцентний методом за допомогою моноклональних антитіл виробництва «Becton Dickinson» (США) і ЗАТ «Сорбент-сервіс» (Росія, Москва) на проточному цитофлюориметрії «Becton Diskinson» (Parks D.R., Lanier L.L., Herrenberg L.A., 1986).

Концентрацію імуноглобулінів ( $\lg$ M, Ig G, Ig A), у сироватці крові визначали методом радіальної імунодифузії в гелі за G. Manchini (1965). Концентрацію лізоцима в сироватці крові визначали із застосуванням сухого порошку однодобової культури Micrococcus lyzodeiticus за методикою Мотавкиної Н.C. (1979).

Статистична обробка отриманих результатів виконувалась варіаційно-статистичним методом із використанням t-критерію Стьюдента.

РЕЗУЛЬТАТИ ДОСЛІДЖЕНЬ ТА ЇХ ОБГОВОРЕННЯ. Визначення основних лімфоцитарних субпопуляцій у жінок із загрозою переривання вагітності та 3 викиднем, що не відбувся, ранніх термінів показало, що кількість T- ^ $D$ 3+) та B- (CD 20+) лімфоцитів, Tхелперних (CD 4+) та Т-супресорно-цитотоксичних (CD $8^{+)}$клітин в крові була практично такою $ж$ як у жінок контрольної групи. Кількісний склад та абсолютна кількість основних субпопуляцій лімфоцитів також не мали розбіжностей і були подібними у всіх обстежених групах, включно із контрольною (табл. 1).

Для виявлення кількості натуральних кілерів (NKклітин) в периферійній крові у жінок обстежених груп, 


\section{Акушерство та гінекологія}

був проведений аналіз кількості лімфоцитів із фенотипом CD $16^{+}$та CD $56^{+}$. Згідно даним літератури, на ранніх етапах розвитку вагітності відзначається різке зниження в крові кількості CD 16+ клітин, оскільки вони $€$ відповідальними за антитіло-залежну клітинну цитотоксичність NK- та Т-лімфоцитів. Ряд досліджень показав достовірне збільшення абсолютної та відносної кількості CD 16+ клітин у жінок із ускладненим перебігом вагітності [4, 7]. Проведений нами аналіз кількісного показника вмісту натуральних кілерів (CD 16+ лімфоцитів) в периферичній крові у обстежених жінок не виявив принципових відмінностей по групам. Поряд с цим, встановлено достовірне збільшення відносної кількості CD 56+ в периферичній крові у жінок обстежених груп в порівнянні із показником жінок із фізіологічним перебігом вагітності, що відповідно становило і першій групі - $(10,7 \pm 0,10) \%$, в другій групі - $(12,7 \pm 0,7) \%$, проти $(7,6 \pm 0,2) \%$ в контролі.

Згідно даним літератури, за умов ускладненого перебігу вагітності може спостерігатись збільшення кількості лімфоцитів, що містять маркери ранньої активації (CD 25+), що відображає готовність їх до проліферації, та свідчить про активацію Th-1-типа імунної відповіді. Такі зміни можуть сприяти порушенню нормального перебігу вагітності за рахунок змін динамічного імунологічного баланса в системі мати-плацента-плід [4, 7]. Порівняння середніх значень вмісту лімфоцитів, що експресують на своїй поверхні маркер ранньої активації (CD 25+) не виявило достовірних змін в порівнянні з контрольною групою (табл. 1 ).

Вагому роль в механізмах збереження клітинного баланса та регульованої клітинної загибелі відіграє апоптоз. За допомогою механізма апоптоза видаляються аутоспецифічні клони та клітини, реалізується клітинно-опосередкованний цитоліз [8]. Враховуючи важливе значення процесів апоптоза в підтримці гомеостаза, був проаналізований вміст лімфоцитів, що експресують Fas рецептор CD 95+, як маркер пізньої активації, який характеризує готовність до апоптозу. Встановлено, що в першій групі спостерігалось достовірне підвищення абсолютної кількості CD 95+ $(433 \pm 70)$ мм $^{3}$, при $(260 \pm 82)$ мм $^{3}$ в контрольній групі та $(371 \pm 76)$ мм $^{3}$ в другій групі. Таким чином, виявлене підвищення кількості CD 95+ у жінок першої групи може вказувати на участь Fas-системи в імунопатогенетичних механізмах загрози переривання вагітності.

Порівняльний аналіз вмісту специфічних та неспецифічних факторів системного імунітету показав, що у жінок з ускладненим перебігом вагітності ранніх термінів, а саме у пацієнток із загрозливим викиднем та викиднем, що не відбувся, концентрація Ig G була достовірно вищою за показник контрольної групи, відповідно, $(13,01 \pm 0,73)$ г/лта $(12,10 \pm 0,76)$ г/л, проти $(8,38 \pm 0,20)$ г/л, р < 0,05 (табл. 2).

При вивченні концентрації ІдМ в сироватці крові жінок досліджуваних груп не було встановлено достовірних відхилень від показника контрольної групи, так у пацієнток першої групи середній показник його концентрації склав $(1,38 \pm 0,13)$ г/л, у жінок другої групи - $(1,06 \pm 0,03)$ г/л. Поряд з цим, зафіксовано достовірне підвищення концентрацій ІдА в сироватці крові у пацієнток обох груп, що, відповідно, склало в першій групі $(2,61 \pm 0,29)$ г/л, в другій групі - $(2,56 \pm 0,22)$ г/л, при $(1,33 \pm 0,23)$ г/л в контролі, $(p<0,05)$.

Характеризуючи концентрації неспецифічного фактору захисту лізоциму, який є основним бактерицидним фактором біологічних рідин, слід зазначити, що його концентрація в сироватці крові у пацієнток обох обстежених груп була достовірно нижчою в порівнянні з показником контрольної групи, що, відповідно, склало в першій групі - $(0,022 \pm 0,006)$ г/л, в другій групі $(0,018 \pm 0,006)$ г/л, проти $(0,058 \pm 0,006)$ г/л в контролі.

Таким чином, за умов ускладненого перебігу вагітності ранніх термінів, виявлені односпрямовані зміни показників специфічних та неспецифічних факторів системного імунітету. За умов загрози переривання

Таблиця 1. Особливості вмісту периферичних лімфоцитів в крові у жінок по групам абс.ч. (\%)

\begin{tabular}{|c|c|c|c|}
\hline \multirow{2}{*}{ Показник } & \multicolumn{3}{|c|}{ Значення показника по групах } \\
\hline & перша & друга & контрольна \\
\hline Лейкоцити, $10^{9} / л$ & $7,1 \pm 0,4$ & $5,6+1,1$ & $6,1+0,7$ \\
\hline Лімфоцити & $\begin{array}{r}1840 \pm 134 \\
(28,5+1,4)\end{array}$ & $\begin{array}{c}1549 \pm 343 \\
(28,0+3,2)\end{array}$ & $\begin{array}{c}1755 \pm 174 \\
(29,3+1,7)\end{array}$ \\
\hline $\mathrm{CD}^{+}$ & $\begin{array}{l}1219+107 \\
66,1+2,0\end{array}$ & $\begin{array}{l}1139 \pm 237 \\
73,9 \pm 4,5\end{array}$ & $\begin{array}{r}1091+112 \\
62,1+1,1\end{array}$ \\
\hline $\mathrm{CD} 4^{+}$ & $\begin{array}{c}780 \pm 69 \\
39,4+2,1\end{array}$ & $\begin{array}{c}704 \pm 91 \\
47,1 \pm 3,9\end{array}$ & $\begin{array}{c}643 \pm 50 \\
37,2+1,5\end{array}$ \\
\hline $\mathrm{CD} 8^{+}$ & $\begin{array}{c}478 \pm 42 \\
24,4+1,2\end{array}$ & $\begin{array}{l}475 \pm 153 \\
29,6 \pm 5,5\end{array}$ & $\begin{array}{c}474 \pm 72 \\
26,6 \pm 2,2\end{array}$ \\
\hline CD 4/CD 8 & $1,7+0,1$ & $1,8+0,6$ & $1,5+0,2$ \\
\hline $\mathrm{CD} 20^{+}$ & $\begin{array}{c}200 \pm 15 \\
10,3+0,1\end{array}$ & $\begin{array}{l}128+21 \\
8,6+1,6 \\
\end{array}$ & $\begin{array}{r}180 \pm 29 \\
9,9 \pm 0,8\end{array}$ \\
\hline CD $16^{+}$ & $\begin{array}{c}214+18 \\
11,4+1,1\end{array}$ & $\begin{array}{c}192 \pm 45 \\
11,5+0,55\end{array}$ & $\begin{array}{c}284 \pm 45 \\
15,9+1,4\end{array}$ \\
\hline $\mathrm{CD} 25^{+}$ & $\begin{array}{l}200 \pm 33 \\
9,5+1,1\end{array}$ & $\begin{array}{l}117+33 \\
6,7+1,1\end{array}$ & $\begin{array}{l}205 \pm 36 \\
9,6 \pm 2,4\end{array}$ \\
\hline CD $95^{+}$ & $\begin{array}{c}(433 \pm 70)^{*} \\
19,6+3,1\end{array}$ & $\begin{array}{c}371 \pm 76 \\
19,3+3,7\end{array}$ & $\begin{array}{c}260 \pm 82 \\
18,1 \pm 4,9\end{array}$ \\
\hline CD $56^{+}$ & $\begin{array}{c}203 \pm 20 \\
(10,7+0,10)^{*}\end{array}$ & $\begin{array}{c}212 \pm 56 \\
(12,7+0,7)^{*}\end{array}$ & $\begin{array}{r}141 \pm 7 \\
7,6 \pm 0,2\end{array}$ \\
\hline
\end{tabular}

Примітка. * Різниця достовірна відносно показника контрольної групи, p<0,05. 


\section{Акушерство та гінекологія}

Таблиця 2. Концентраціїімуноглобулінів G, М, А та лізоциму у сироватці крові жінок по групах г/л

\begin{tabular}{|l|c|c|c|}
\hline \multirow{2}{*}{ Показник } & \multicolumn{3}{|c|}{ Значення показника по групах } \\
\cline { 2 - 4 } & перша & друга & контрольна \\
\hline IfIG & $(13,01+0,73)^{\prime \prime}$ & $1,08+0,11$ & $1,06 \pm 0,20$ \\
\hline ig m & $1,38+0,13$ & $(2,56 \pm 0,22)^{*}$ & $1,33 \pm 0,23$ \\
\hline ig a & $(2,61+0,29)^{\prime \prime}$ & $(0,018+0,006)^{\prime \prime}$ & $0,058 \pm 0,006$ \\
\hline Лізоцим & $(0,022+0,005) "$ & \\
\hline
\end{tabular}

Примітка. * Різниця достовірна відносно показника контрольної групи, $p<0,05$

вагітності спостерігалось достовірне збільшення концентрації lg G та Ід А на тлі 2,5 разового зменшення концентрації лізоциму. За умов викидня, що не відбувся, спостерігалось достовірне збільшення концентрації Ід G, Ід А на тлі зменшення концентрації лізоциму в 3,2 рази. Виявлені зміни імунологічного гомеостазу у жінок із ускладненим перебігом вагітності вказують на наявність хронічного запального процесу, як однієї з ланок патогенезу ранніх втрат вагітності.

ВИСНОВКИ. У жінок із загрозою переривання вагітності та викиднем, що не відбувся, ранніх термінів, відзначались суттєві зміни клітинного, гуморального імунітету, що свідчили про напруженість процесів імуногенезу.

За умов переривання вагітності ранніх термінів імунопатологічні зрушення характеризуються збільшенням кількості клітин із кілерною активністю CD $56^{+}$та підвищення маркеру пізньої активації CD $95^{+}$, що свідчить про порушення процесів апоптоза імунокомпетентних клітин.

Для завмерлої вагітності ранніх термінів характерно збільшення клітин із хелперно-індукторними та кілерними властивостями CD 4+, CD $56+$.
Виявлені зміни показників специфічних та неспецифічних факторів системного імунітету, які полягали у достовірному збільшенні концентрації Ід $\mathrm{G}$ та Ід $\mathrm{A}$ та зниженні вмісту лізоциму у сироватці крові у жінок із загрозою переривання вагітності та викиднем, що не відбувся, ранніх термінів концентрації вказують на наявність хронічного запального процесу, як однієї $з$ ланок патогенезу ранніх втрат вагітності.

ПЕРСПЕКТИВИ ПОДАЛЬШИХ ДОСЛІДЖЕНЬ. На нашу думку, безумовний науковий інтерес представляє подальше поглиблене імунологічне дослідження на рівні децидуальної оболонки та хоріону в співставленні із результатами отриманими при дослідженні гуморального та клітинного імунітета, що дасть змогу дослідити наявність кореляційний взаємозв'язків, розкрити нові патогенетичні аспекти. Отримані дані необхідні для розробки та впровадження нових ефективних схем лікування та прегравідарної підготовки жінок, які направлені на запобігання майбутніх репродуктивних втрат.

\section{ЛІТЕРАТУРА}

1. Радзинский В.Е. Генетические и иммунологические аспекты привычного невынашивания беременности / В.Е. Радзинский, Е.Ю. Запертова, В.В. Мисник//Акуш. и гин. 2005.- № 6. - С. 24-29.

2. Подзолкова Н.М. Невынашивание беременности: учебно-методические рекомендации / Н.М. Подзолкова, М.Ю. Скворцова. - М., 2010. - 52 с.

3. Beaman D. Immune etiology of recurent pregnancy loss and its diagnosis/D. Beaman, E. Ntrivalas, TM. Mailers [etal.] I/Am. J. Reprod. Immunol. - 2012. - Vol. 10. - P. 1111-1118.

4. Тетруашвили Н.K. Ранние потери беременности (иммунологические аспекты, пути профилактики и терапии): автореф. дисс. на соискание учен. степени докт. мед. наук: спец. 14.01.01 «Акушерство и гинекология»/ Н.К. Тетруашвили. - Москва, 2008. - 38 с.
5. Ширшев С.В. Механизмы иммунноэндокринного контроля процессов репродукции / Ширшев С.В. - Екатеринбург: УрО РАН, 2002. - 428 с.

6. Сухих Г.Т. Иммунные механизмы в физиологии и патологии беременности / Г.Т. Сухих, Л.В. Ванько // Иммунология. 2005.- Т. 9, №2. -С.103-108.

7. Макаров О.В. Изменение показателей иммунитета у пациенток с невынашиванием беременности инфекционного генеза в I триместре / О.В. Макаров, Л.А. Озолиня, Т.Н. Сумеди //Российский вестник акушера-гинеколога. - 2008. - № 6 . - С. 28-32.

8. Подоляка Д.В Апоптоз и репродуктивное здоровье женщины/Д.В. Подоляка//Здоровье женщины. -2004. № 1 (17). - С . 152-155. 